\title{
SELECTED INTERNET SOURCES ON CIVIL EMERGENCY AND LAW ENFORCEMENT ISSUES
}

\section{US Federal Emergency Management Agency (FEMA)}

http://www.fema.gov

FEMA is the lead agency in the United States to response an event that has occurred and consequence management. The FEMA site provides emergency management courses for self-study.

\section{Awareness of National Security Issues and Response (ANSIR)}

http://www.fbi.gov/ansir/

The ANSIR program of the United States Government is designed to provide unclassified national security threat and warning information to US corporate security directors and executives, law enforcement and other government agencies. It focuses on the response capability unique to the jurisdiction of the Federal Bureau of Investigation in both law enforcement and counterintelligence.

\section{Interagency Group on Counterterrorism}

http://www.state.gov/s/ct/

In the US, The Department of State is the lead agency for overseas terrorist actions and supports the Office of the Coordinator for Counterterrorism that chairs the Interagency Group on Counterterrorism.

\section{The International Policy Institute for Counter-Terrorism (ICT)}

http://www.ict.org.il

ICT, established in 1996, focuses solely on the subject of counter-terrorism. It approaches the issue of terrorism as a strategic problem. The Institute raises public awareness and provides advice to decision makers. The site provides articles by ICT staff, terrorist organizations' profiles and databse of terror attacks. 


\section{Defense Threat Reduction Agency (DTRA)}

http://www.dtra.mil/

DTRA is a US Department of Defense Agency with the mission to reduce the threat to the United States and its allies from nuclear, biological, chemical (NBC), conventional and special weapons through the execution of technology security activities, cooperative threat reduction programs, arms control treaty monitoring and on-site inspection, force protection, NBC defense, and counter proliferation; to support the US nuclear deterrent; and to provide technical support on weapons of mass destruction matters to DoD components.

\section{Chem-Bio Defense}

http://www.dtra.mil/cb/cb_index.html

Chemical and biological weapons, sometimes referred to as the "poor man's nuclear weapons," pose a significant threat in the post-Cold War environment. In order to counter these threats more effectively and develop better means of responding, DTRA draws upon the disparate chemical and biological weapons defense expertise in the Department of Defense in acting as the focal point for DoD technical expertise in these areas. In doing so, the Agency directs and manages Chem-Bio defense efforts in a centralized and focused manner in pursuit of proper preparation and response in the event of a chemical or biological weapons attack against U.S. forces or territory, or those of allies.

\section{Environmental Protection Agency, US}

http://www.epa.gov

EPA's mission is to protect human health and to safeguard the natural environment air, water, and land - upon which life depends. The EPA's Chemical Emergency Protection and Preparedness Office <http://www.epa.gov/ceppo> offers technical assistance to prevent and prepare for chemical emergencies, respond to environmental crisis, and inform the public about chemical hazards in their community.

\section{US National Domestic Preparedness Office, Department of Justice}

http://www.ndpo.com

The mission of NDPO is to coordinate all federal efforts, including the efforts of the Department of Defense, FEMA, Department of Health, Department of Energy and the 
Environmental Protection Agency to assist state and local first responders with planning, training, equipment and exercise necessary to respond to an incident with conventional or non-conventional weapons of mass destruction. NDPO provides training, coordinated equipment, coordinated exercises and integrated planning.

\section{US National Infrastructure Protection Center}

http://www.nipc.gov/

The National Infrastructure Protection Center (NIPC) serves as a national critical infrastructure threat assessment, warning, vulnerability, and law enforcement investigation and response entity. The NIPC provides timely warnings of international threats, comprehensive analysis and law enforcement investigation and response. The mission of the NIPC is to: detect, deter, assess, warn, respond, and investigate unlawful acts involving computer and information technologies and unlawful acts, both physical and cyber, that threaten or target our critical infrastructures; manage computer intrusion investigations; support law enforcement, counterterrorism, and foreign counterintelligence missions related to cyber crimes and intrusion; support national security authorities when unlawful acts go beyond crime and are foreign-sponsored attacks on United States interests; and coordinate training for cyber investigators and infrastructure protectors in government and the private sector.

\section{Comprehensive Risk Analysis and Management Network (CRN)}

http://www.isn.ethz.ch/crn/

$\mathrm{CRN}$ is an electronic platform for promoting the risk profiling dialogue. The site contains methodologies, procedures, tools and case studies for the security risk profiling process at national, sub-national and local levels. CRN is developed by the Center for Security Studies and Conflict Research at the ETH Zurich with the Swedish Agency for Civil Emergency Planning (ÖCB) <www.ocb.se $>$ and the Swiss Federal Office for Civil Protection <www.zivilschutz.admin.ch>.

\section{UNOCHA - The United Nations Office for the Coordination of Humanitarian Affairs}

The Emergency Relief Coordinators functions of UNOCHA are focused in three core areas: (a) policy development and coordination functions in support of the SecretaryGeneral, ensuring that all humanitarian issues, including those which fall between gaps in existing mandates of agencies such as protection and assistance for internally displaced persons, are addressed; (b) advocacy of humanitarian issues with political 
organs, notably the Security Council; and (c) coordination of humanitarian emergency response, by ensuring that an appropriate response mechanism is established, through Inter-Agency Standing Committee (IASC) consultations, on the ground. International Strategy for Disaster Reduction (ISDR) is one of the UNOCHA projects. The mission of the project is to help communities reduce the risk of longer-term social and economic disruption in the face of a natural hazard by helping then assess their vulnerabilities to these risks and plan to increase their resiliency to disaster. For more information see http://www.unisdr.org/unisdr/ safer.htm.

\section{The Fribourg Forum: Managing Crisis}

http://www.reliefweb.int/fribourg/

The Fribourg Forum is part of the European Cooperation Program that aims at creating favorable environment for effective crisis management and humanitarian action within existing regional mechanisms. The purpose of the Fribourg Forum is to convene senior policy makers responsible for international humanitarian assistance in Europe and the USSR successor states in order to obtain their support and commitment for an enhanced coordination and cooperation in the provision of humanitarian assistance in the region. In this respect, the Fribourg Forum gives opportunity to governments and international/regional organizations to present initiatives and programs addressing the current challenging crisis management situation as well as identifying areas of concern calling for particular attention.

\section{International Civil Defense Organization (ICDO)}

http://www.icdo.org/

The International Civil Defense Organization (ICDO) is an intergovernmental organization whose objective is to contribute to the state development of structures ensuring the protection and assistance of populations and safeguarding property and the environment from natural or man-made disasters. These structures are generally known as civil protection, civil defense or civil safety and are all concerned with the management of emergency situations. ICDO is active mainly in international cooperation in civil protection matters, development of national civil protection structures, and promotion of disaster prevention

\section{Hazard and Risk Assessment within OECD}

The Organization for Economic Co-operation and Development (OECD) groups 29 member countries in an organization that, most importantly, provides governments a 
setting in which to discuss, develop and perfect economic and social policy. They compare experience, seek answers to common problems and work to co-ordinate domestic and international policies that increasingly in today's globalized world must form a web of even practice across nations. OECD has ongoing projects in the following areas:

\section{Hazard / Risk Assessment}

Many activities on hazard/risk assessment are currently going-on within the OECD. The activities are being carried out under various programs (e.g. Existing Chemicals Program, and the Pesticides Program). Of particular interest is the promotion of risk communication and the convergence of chemical risk assessment and socio-economic analysis <http://www.oecd.org/ehs/hazard.htm>.

\section{Chemical Risk Management}

OECD's Environmental Health and Safety Program publishes a Chemical Risk Management series at http://www.oecd.org/ehs/risk.htm.

\section{International Futures Program}

The OECD has launched a promising initiative to conduct a thorough examination of the changing nature of systemic risks and its implications. The purpose of this OECD "Futures Project on Emerging Systemic Risks" is to provide OECD governments, major players in the business sector as well as civil society, with a comprehensive picture of possible future developments in this field. It will also offer an opportunity for the development of a common assessment of the means needed to ensure that risk management can contribute fully to the sound and sustainable evolution of the OECD area and the world economy at large over the coming decades. <http://www.oecd.org/ sge/au/risks.htm>

\section{The OECD/IPCS Database on Hazard/Risk Assessment Methodologies}

The OECD/IPCS Database on Hazard/Risk Assessment Methodologies includes hazard/risk assessment methodologies for industrial chemicals and pesticides and for human health and environmental assessments. <http://www.oecd.org//ehs/RA/riskassessment-methodologies.htm>

\section{EUR-OPA Major Hazards Agreement}

http://www.europarisks.coe.int/

The mission of the Cooperation Group for the Prevention of, Protection against, and Organization of Relief in Major Natural and Technological Disasters is to provide for open dissemination of information and training of populations in the field of risk 
management, establishment of a permanent telecommunications link between the persons responsible for risk management in the member states of the EUR-OPA Major Hazards Agreement, resolution on cooperation between the EUR-OPA Major Hazards Agreement and international institutions, resolution on the network of specialized centers of the Agreement, and establishment of a "Risk Culture."

\section{The CERT Analysis Center}

http://www.cert.org/analysis

The CERT analysis Center seeks to assess and predict online threats. The site currently provides documents on cyberwar, information security trend analysis, cyberterrorism, and intelligence analysis for Internet security.

\section{OECD Anti-Corruption Activities}

http://www.oecd.org/ <Corruption>

At its web site, the Organization for Economic Co-operation and Development (OECD) maintains information on international policy initiatives, conventions and reports on: Bribery and Export Credits; Corruption and Development; Ethics and Corruption; Fighting Bribery and Corruption; and Tax Treatment of Bribes. Furthermore, OECD pays special attention to money laundering. The latest annual report, 22 June 2001, of the Financial Action Task Force on Money Laundering is available at http://www1.oecd.org/fatf/pdf/AR2000_en.pdf.

\section{SEECAP}

http://www.nato.int/docu/comm/2001/0105-bdp/d010530b.htm

The South East Europe Common Assessment Paper on Regional Security Challenges and Opportunities (SEECAP) is endorsed by the States of the region of South Eastern Europe as a first hand perception of how these challenges and opportunities can guide the common efforts to foster lasting peace, stability, freedom and prosperity. The paper pays special attention to non-conventional security challenges such as organized crime and terrorism.

\section{UN Center for International Crime Prevention}

www.odccp.org/about.html

The United Nations Office for Drug Control and Crime Prevention (ODCCP) is a global leader in the fight against illicit drugs and international crime. Established in 
1997, ODCCP consists of the United Nations International Drug Control Program (UNDCP) and the United Nations Center for International Crime Prevention (CICP).

\section{UNDCP}

www.odccp.org/undcp.html

Founded in 1991, the United Nations International Drug Control Program UNDCP works to educate the world about the dangers of drug abuse. The Program aims to strengthen international action against drug production, trafficking and drug-related crime through alternative development projects, crop monitoring and anti-money laundering <www.odccp.org/money_laundering.html> programs. UNDCP also provides statistics and helps to draft legislation and train judicial officials as part of its Legal Assistance Program.

\section{CICP}

www.odccp.org/crime_cicp.html

Established in 1997, the Center for International Crime Prevention (CICP) is the United Nations office responsible for crime prevention, criminal justice and criminal law reform. The CICP works with Member States to strengthen the rule of law, promote stable and viable criminal justice systems and combat the growing threat of transnational organized crime through its Global Program Against Corruption <www.odccp.org/corruption.html>, Global Program Against Organized Crime $<$ www.odccp.org/organized_crime.html > and Global Program Against Trafficking in Human Beings <www.odccp.org/trafficking_human_beings.html> and its Terrorism Prevention Branch (TPB) <www.odccp.org/terrorisam.html>.

\section{INCB}

www.odccp.org/incb.html

The International Narcotics Control Board (INCB) is the independent and quasijudicial control body for the implementation of the United Nations drug conventions. It was established in 1968. INCB is independent of Governments as well as of the United Nations; its 13 members serve in their personal capacity.

\section{UN Commission on Crime Prevention and Criminal Justice}

www.odccp.org/crime_cicp_commission.html

The 40-member UN Commission on Crime Prevention and Criminal Justice formulates international policies and recommends activities in the field of crime control. The Commission offers nations a forum for exchanging information and to settle on ways to fight crime on a global level. The Commission is a subsidiary body of the Economic and Social Council. The Commission formulates draft resolutions for action by the Council. These resolutions eventually direct the work of the CICP. 


\section{Institute for Crisis, Disaster, and Risk Management}

http://www.seas.gwu.edu/ icdm/

The Institute for Crisis, Disaster, and Risk Management (ICDRM) at The George Washington University was established in August 1994 as an interdisciplinary academic center affiliated with the University's School of Engineering and Applied Science, School of Medicine and Health Sciences, School of Public Health and Health Services, and Elliott School of International Affairs. The Institute integrates the existing diverse expertise and research related to crisis, disaster, and risk management at the George Washington University and is unique in its interdisciplinary focus and structure. This interdisciplinary approach produces innovative research, training, and education to enhance crisis and emergency management, risk management, contingency planning, emergency response, and disaster recovery. Some of its research results are presented on-line, e.g., the report on "Future of Emergency Management in the US following Sept. 11 Terror Attacks," October $2001<$ http://www.seas.gwu.edu/ icdm/Oct1.htm>.

\section{Disaster Preparedness and Prevention}

http://www.stabilitypact.org/stabilitypactcgi/catalog/cat_descr.cgi?subcat=1\&prod_id $=48$

The Disaster Preparedness and Prevention Initiative (DPPI) is an effort by the Stability Pact for South Eastern Europe to contribute to the development of a cohesive regional strategy for disaster preparedness and prevention. It aims to bridge the gap between international and local efforts and to encourage the full participation and mutual support of all regional countries. An operational team, with expert personnel from the Bulgaria, Croatia, Italy, Sweden, the United States, the International Federation of Red Cross and Red Crescent Societies (IFRC), NATO, and the United Nations Development Program (UNDP), was established to provide the technical background work. As the first stage in developing a strategy, the DPPI undertook an assessment in each country of the region. The team assessed disaster preparedness and prevention needs and capabilities, reviewed natural and technological disaster risks and existing disaster management and preparedness plans, and identified ongoing emergency response projects, coordination structures and procedures. The findings will serve as basis for the development of a comprehensive Disaster Preparedness and Prevention Strategy for South Eastern Europe. This strategy will be developed in cooperation with the countries and validated by them. The main strategies and lines of work identified for improving the overall disaster management capacity in the region will be addressed at the national, bi-national, multi-national or regional level. 


\section{GAMMA-EC}

http://www.tno.nl/instit/fel/gamma_ec/

International research project within the European Union on technology, methods and organization to increase public safety in a number of hazards and emergencies. 